\title{
Goldenberry (Physalis peruviana L.) seed oil: press extraction, optimization, characterization,
} and oxidative stability

\author{
Pedro P. Ugarte-Espinoza ${ }^{1}$, Victor Delgado-Soriano ${ }^{1}$, Lorenzo Estivi ${ }^{2}$, Alyssa Hidalgo ${ }^{2 *}$, Gloria Pascual-Chagman ${ }^{1}$ \\ ${ }^{1}$ Departamento de Tecnología de Alimentos y Productos Agropecuarios, Facultad de Industrias Alimentarias, Av. La \\ Universidad s/n. La Molina, Universidad Nacional Agraria La Molina (UNALM), Lima, Perú; ${ }^{2}$ Department of Food, \\ Environmental and Nutritional Sciences (DeFENS), Università degli Studi di Milano, Milan, Italy
}

"Corresponding Author: Alyssa Hidalgo, Department of Food, Environmental and Nutritional Sciences (DeFENS), Università degli Studi di Milano, Italy. Email: alyssa.hidalgovidal@unimi.it

Received: 18 October 2021; Accepted: 10 December 2021; Published 26 December 2021

(c) 2021 Codon Publications

OPEN ACCESS (C) (1) (2)(2)

PAPER

\begin{abstract}
In order to optimize the screw-press extraction conditions of oil from goldenberry (Physalis peruviana L.) seeds obtained from nectar processing waste, a face centered design was applied. The oil was extracted at different temperatures $\left(60,80\right.$, and $\left.100^{\circ} \mathrm{C}\right)$ and seed moisture contents $(8,10$, and $12 \%)$. Oil recovery (OR) increased and residual oil in the cake decreased significantly as moisture content and temperature were reduced; oil moisture and volatile matter as well as acid value, $\mathrm{K}_{232}, \mathrm{~K}_{268}$, and $p$-anisidine, respectively, decreased proportionally with the moisture extraction. Thus, the highest OR $(86.4 \%)$ and the best quality were obtained at $8 \%$ moisture content and $60^{\circ} \mathrm{C}$ pressing temperature. Under these conditions, the extracted oil presented high linoleic acid (76.0\%), iodine value $(140.0 \mathrm{mg} \mathrm{I} / \mathrm{g}$ ), and refractive index (1.4769). The oil stability index, measured by Rancimat, varied from $3.65 \mathrm{~h}\left(120^{\circ} \mathrm{C}\right)$ to $14.87 \mathrm{~h}\left(100^{\circ} \mathrm{C}\right)$; the predicted shelf life at $25^{\circ} \mathrm{C}$ was 120.4 days and the activation energy was 85.6 $\mathrm{kJ} / \mathrm{mol}$. The results highlighted that screw-pressing of goldenberry seeds provides quality oil without employing polluting and hazardous solvents.
\end{abstract}

Keywords: cape gooseberry; expeller; oil recovery; oxidation kinetics; Rancimat; shelf life

\section{Introduction}

Physalis peruviana L., commonly known as goldenberry or Cape gooseberry, is a perennial herb native of the Andean highlands belonging to the Solanaceae family. P. peruviana has become one of the most promising tropical fruits and has received growing interest from all over the world due to its potential as an intensive crop with a high content of bioactive compounds (Etzbach et al., 2018; Ramadan, 2020).

The fruit when fresh is used as decoration in meals, salads, and desserts; when processed is used in sauces, jam, syrup, and yogurt (Chasquibol Silva and Yácono Llanos,
2015; Ramadan and Mörsel, 2003); and when dehydrated is used in baked foods, cocktails, snacks, and cereal breakfast (Vásquez-Parra et al., 2013). The food industry produces juices and nectars from goldenberry pulp, discarding seeds and peels (ca. 27\% fruit fresh weight, Ramadan, 2020) as by-products. The amount of seeds compared to the fresh fruit weight is rather variable: Ramadan and Mörsel (2003) reported that seeds constituted $17 \%$ of the fruit's weight, whereas Popova et al. (2020) found this to be 7.3 and $11.5 \%$ in two different genotypes. The seeds are a potential raw material for oil production because of their high oil content (Aslanov et al., 1995; Chasquibol Silva and Yácono Llanos, 2015; Popova et al., 2020) and high nutritional value. In addition, 
they are an important source of linoleic acid (omega 6) and vitamins A, E, and K (Chasquibol Silva and Yácono Llanos, 2015; Ramadan and Mörsel, 2003), as well as of phenolic compounds. Furthermore, no adverse effects or toxicity are reported (Nocetti et al., 2020).

In previous studies, oil from goldenberry pomace (seeds, peels, and pulp remnants) was obtained by aqueous enzymatic extraction and solvent extraction (Mokhtar et al., 2018; Ramadan et al., 2008; Ramadan and Moersel, 2009). However, these methods have certain disadvantages related to performance, economy, and safety. For instance, the aqueous enzymatic extraction has low yields and high costs of enzymes (Mwaurah et al., 2020). On the other hand, solvent extraction requires expensive facilities and equipment, and has the risk of fire and explosion associated with the flammable nature of solvents (Deli et al., 2011). They are also harmful to both human health and environment as pollutants (Mwaurah et al., 2020).

Hence, mechanical extraction using a screw press is a cheaper, safer, and simpler alternative. Although goldenberry seed oil (GSO) has already been extracted using this method (Chasquibol Silva and Yácono Llanos, 2015), the effect of extraction conditions on oil yield and quality was not investigated. Likewise, no characterization of GSO oxidation kinetic or shelf-life prediction by Rancimat is available in literature.

Therefore, the objective of this research was to optimize the screw-press extraction process of oil from goldenberry seeds, as well as to characterize and evaluate the oxidative stability by Rancimat of the oil obtained at the best extraction conditions.

\section{Materials and Methods}

\section{Raw material}

The goldenberry pomace (peel, seed, and pulp remains) obtained during the nectar production process at the Agroindustrial Development Institute-INDDA (LimaPeru) was used. After removing the peels and pulp residual by washing with water, the seeds were dried at $50^{\circ} \mathrm{C}$ for $17 \mathrm{~h}$, sieved, and stored at $4^{\circ} \mathrm{C}$ in hermetic low-density polyethylene bags until the extraction trials.

\section{Optimization trials for oil screw-press extraction}

Response surface methodology was used to evaluate the effect of different extraction conditions on the response variables, namely, oil recovery (OR), residual oil ( $\mathrm{RO})$, oil moisture and volatile matter, acid value (AV), peroxide value (PV), specific extinction at 232 and $268 \mathrm{~nm}\left(\mathrm{~K}_{232}\right.$ and
$\mathrm{K}_{268}$ ), and $p$-anisidine value ( $p$-AV). The experiments were carried out following a face centered design (FCD), considering temperature $\left(-1=60^{\circ} \mathrm{C},+1=100^{\circ} \mathrm{C}\right)$ and moisture $(-1=8 \%,+1=12 \%)$ as independent variables. The FCD was performed considering three central points, with a total of 11 runs according to Table 1 . To avoid systematic errors, the experiments were performed randomly.

\section{Oil extraction}

The seeds were hydrated with distilled water until moisture levels of 8,10 , and $12 \%$, according to the methodology indicated by Singh and Bargale (2000). The hydrated seeds were packed in hermetic containers and stored at room temperature for approximately $48 \mathrm{~h}$ to reach equilibrium. The containers were shaken at regular intervals to distribute the moisture evenly throughout the seeds. The amount of water necessary for hydration was determined by applying the following formula (Mridula et al., 2019): $M_{W}=M_{S} \frac{\left(H_{1}-H_{0}\right)}{100-H_{1}}$, where $M_{W}$ is the mass of water to be added ( $\mathrm{g}$ ), $\mathrm{M}_{\mathrm{S}}$ is the mass of seeds to be hydrated (g), $\mathrm{H}_{0}$ and $\mathrm{H}_{1}$ are, respectively, the initial and the final moisture content $(\mathrm{wb})$ of the seeds.

The seeds were pressed at 60,80 , and $100^{\circ} \mathrm{C}$, using a KOMET screw press (CA 59 G, IBG Monforts, Germany), at a screw speed of 15 RPM and a nozzle diameter of $4 \mathrm{~mm}$. Before introducing the seeds into the feed hopper, the press was operated for $15 \mathrm{~min}$ with heating through the electric resistance ring fixed around the press head to raise the temperature of the cylinder to the selected temperature. After each run, all press devices were cleaned and dried. The oils obtained were centrifuged (ROTOFIX $32 \mathrm{~A}$, Hettich, Germany) at 2,701 $\mathrm{g}$ for $30 \mathrm{~min}$ and subsequently stored in amber bottles at $4^{\circ} \mathrm{C}$ until analysis. The cakes obtained were stored at $4^{\circ} \mathrm{C}$ in hermetic low-density polyethylene bags until analysis.

\section{Analyses}

All the following determinations were performed in triplicate.

\section{Seed characterization}

The moisture, crude fat, ash, crude fiber, and crude protein $(\mathrm{N} \times 6.25)$ of the seeds were determined following the AOAC methods, 935.29, 945.16, 950.49, 962.09, and 950.48 (AOAC International, 2016), respectively. The total carbohydrate content was determined by difference, i.e. by subtracting all the above mentioned compounds from the total. 
Table 1. Experimental design and average results for oil recovery $(\%)$, residual oil ( $\% \mathrm{dm})$, moisture and volatile matter $(\%)$, acid value ( $\mathrm{mg} \mathrm{KOH} / \mathrm{g}), p$-anisidine value, extinction coefficients $\mathrm{K}_{232}, \mathrm{~K}_{268}$ of goldenberry seed oil obtained at different press extraction conditions (temperature, ${ }^{\circ} \mathrm{C}$; moisture, $\mathrm{g} / 100 \mathrm{~g}$ ).

\begin{tabular}{|c|c|c|c|c|c|c|c|c|c|}
\hline \multirow{2}{*}{$\begin{array}{l}\text { Standard } \\
\text { order }\end{array}$} & \multicolumn{2}{|c|}{ Independent variables } & \multicolumn{7}{|c|}{ Response variables } \\
\hline & Temperature & Moisture & Oil recovery & Residual oil & $\begin{array}{l}\text { Moisture and } \\
\text { volatile matter }\end{array}$ & Acid value & p-anisidine & $\mathrm{K}_{232}$ & $\mathrm{~K}_{268}$ \\
\hline 1 & $60(-1)$ & $8(-1)$ & $86.43^{a}$ & $6.62^{\mathrm{h}}$ & $0.072^{d}$ & $0.237^{c}$ & $0.72^{\mathrm{d}}$ & $1.33^{e}$ & $0.17^{\mathrm{e}}$ \\
\hline 2 & $100(1)$ & $8(-1)$ & $65.46^{d}$ & $15.66^{e}$ & $0.075^{\mathrm{d}}$ & $0.234^{c}$ & $0.73^{d}$ & $1.36^{\mathrm{de}}$ & $0.19^{\text {de }}$ \\
\hline 3 & $60(-1)$ & $12(1)$ & $56.15^{f}$ & $18.57^{d}$ & $0.097^{a}$ & $0.360^{\mathrm{ab}}$ & $1.00^{b}$ & $1.49^{a}$ & $0.25^{\mathrm{a}}$ \\
\hline 4 & $100(1)$ & $12(1)$ & $34.98^{i}$ & $25.26^{a}$ & $0.097^{a}$ & $0.382^{\mathrm{a}}$ & $1.04^{\mathrm{a}}$ & $1.50^{\mathrm{a}}$ & $0.26^{a}$ \\
\hline 5 & $60(-1)$ & $10(0)$ & $78.27^{b}$ & $10.01^{\mathrm{g}}$ & $0.087^{b}$ & $0.350^{\mathrm{ab}}$ & $0.83^{c}$ & $1.40^{\mathrm{bc}}$ & $0.21^{c}$ \\
\hline 6 & $100(1)$ & $10(0)$ & $48.95^{9}$ & $21.01^{c}$ & $0.087^{b}$ & $0.373^{a}$ & $0.84^{c}$ & $1.42^{b}$ & $0.22^{b}$ \\
\hline 7 & $80(0)$ & $8(-1)$ & $73.03^{c}$ & $13.13^{f}$ & $0.075^{d}$ & $0.236^{c}$ & $0.73^{d}$ & $1.34^{\mathrm{e}}$ & $0.19^{\mathrm{de}}$ \\
\hline 8 & $80(0)$ & $12(1)$ & $43.51^{h}$ & $22.45^{b}$ & $0.097^{a}$ & $0.361^{\mathrm{ab}}$ & $0.99^{b}$ & $1.49^{a}$ & $0.26^{\mathrm{a}}$ \\
\hline 9 & $80(0)$ & $10(0)$ & $57.35^{\mathrm{e}}$ & $18.46^{d}$ & $0.086^{b c}$ & $0.338^{b}$ & $0.84^{c}$ & $1.41^{b}$ & $0.21^{b c}$ \\
\hline 10 & $80(0)$ & $10(0)$ & $56.42^{f}$ & $18.82^{d}$ & $0.088^{b}$ & $0.369^{\mathrm{ab}}$ & $0.84^{c}$ & $1.38^{\mathrm{cd}}$ & $0.20^{\text {cd }}$ \\
\hline 11 & $80(0)$ & $10(0)$ & $56.83^{\text {ef }}$ & $18.79^{d}$ & $0.084^{c}$ & $0.371^{\mathrm{ab}}$ & $0.84^{c}$ & $1.40^{\mathrm{bc}}$ & $0.20^{\text {cd }}$ \\
\hline
\end{tabular}

Different letters in the same column indicate significant differences $(P \leq 0.05)$ among trials following the LSD test.

\section{Oil recovery (OR) and residual oil (RO)}

The oil recovery (OR) of the oil extracted was calculated using the formula indicated by Mridula et al. (2019):

$$
\mathrm{OR}(\%)=\left[1-\frac{\text { Oil content on cake }(\mathrm{g})}{\text { Oil content in seeds }(\mathrm{g})}\right] \times 100
$$

The oil content in the seeds before pressing extraction and in the cake was assessed following method 945.16 (AOAC International, 2016). The residual oil (RO) was determined from the oil content in the cake after pressing.

\section{Physicochemical analyses of the oils}

Moisture and volatile matter, acid value (AV), peroxide value (PV), refractive index at $20^{\circ} \mathrm{C}, p$-anisidine value $(p-\mathrm{AV})$, iodine value (IV), saponification value (SV), and unsaponificable matter were determined following the methods Ca 2d-25, Ca 5a-40, Cd 8-53, Cc 7-25, Cd 18-90, Cd 1d-92, Cd 3-25, and Ca-40 (AOCS, 1998), respectively. Specific extinction at 232 and $268 \mathrm{~nm}\left(\mathrm{~K}_{232}\right.$ and $\mathrm{K}_{268}$ ) was determined following the method, ISO 3656 (ISO, 2011).

The fatty acids' (FA) composition was determined as fatty acid methyl esters (FAME) by gas chromatography after transesterification of the oils with $2 \mathrm{~N} \mathrm{KOH}$ in methanol, according to IUPAC Standard Method 2.302 (IUPAC, 1987). The fatty acid profile was determined by gas chromatography as described by Rodríguez et al. (2021).

\section{Evaluation of oil oxidative stability (OSI)}

\section{Rancimat test}

The OSI of each oil and of the blends were evaluated by the method AOCS Cd 12b-92 (AOCS, 1998) using a 743 Rancimat equipment (Metrohm Schweiz AG, Zofigen, Switzerland). The assays were carried out using $3.0 \pm$ $0.1 \mathrm{~g}$ of oil sample with an air flow of $20 \mathrm{~L} / \mathrm{h}$ at 100,110 , and $120^{\circ} \mathrm{C}$.

\section{Oil shelf life}

The prediction of shelf life was determined by extrapolation of the linear correlation of the logarithm of OSI vs temperature ( $\mathrm{T}$ ) for a temperature of $25^{\circ} \mathrm{C}$, as described by Heidarpour and Farhoosh (2018): $\log \mathrm{OSI}=a \mathrm{~T}+b$, where $a$ and $b$ represent the slope and intercept, respectively.

\section{Oxidation kinetics}

The reaction rate constant $(k)$ was calculated as the reciprocal of OSI $(k=1 / \mathrm{OSI})$, as indicated by Aktar and Adal (2019). The temperature coefficient $\left(\mathrm{Q}_{10}\right)$, which indicates the increase in reaction rate due to a $10^{\circ} \mathrm{C}$ rise in temperature, was calculated according to Symoniuk et al. (2017): $\mathrm{Q}_{10}=\left(\mathrm{k}_{2} / \mathrm{k}_{1}\right)^{10 /\left(\mathrm{T}_{2}-\mathrm{T}_{1}\right)}$. The relationship between $\mathrm{k}$ and temperature was defined by the Arrhenius equation:

$\ln k=\ln A-E a / R T$, where $\mathrm{A}$ is the frequency factor $\left(\mathrm{h}^{-1}\right)$, $E a$ is the activation energy $(\mathrm{kJ} / \mathrm{mol}), \mathrm{R}$ is the universal gas 
constant $(8.314 \mathrm{~J} / \mathrm{mol} \mathrm{K})$, and $\mathrm{T}$ is the absolute temperature $(\mathrm{K})$.

\section{Statistical analysis}

The analyses of variance (ANOVA) of data and construction of response surface plots were performed using Design Expert software v.12 (Stat-Ease Inc., Minneapolis, USA). Before the ANOVA, normal data distribution was verified. The data were also processed by one-way ANOVA; when significant differences at $\mathrm{P} \leq 0.05$ were found, Fisher's Least Significant Difference (LSD) at P $\leq$ 0.05 was determined. These statistical analyses were performed with the Statgraphics ${ }^{\circ}$ Centurion XVI program (Statpoint Technologies, USA). The data are presented as mean \pm standard deviation (SD) of three replicates, computed using the software Excel (Microsoft ${ }^{\circ}$ Office Excel 2016).

\section{Results and Discussion}

\section{Seed composition}

The proximate chemical composition of the goldenberry seeds was $33.63 \pm 0.03 \mathrm{~g} / 100 \mathrm{~g}$ dry matter for crude fat, similar to the level $(32.7 \mathrm{~g} / 100 \mathrm{~g}$, i.e., $18.09 \mathrm{~g} / 100 \mathrm{~g}$ extracted oil $+14.63 \mathrm{~g} / 100 \mathrm{~g}$ in the cake) observed by Chasquibol Silva and Yácono Llanos (2015), but much higher than the value $(18 \mathrm{~g} / 100 \mathrm{~g})$ reported by Aslanov et al. (1995) in seeds from Azerbaijan. The seeds also contained $14.46 \pm 0.05 \mathrm{~g} / 100 \mathrm{~g} \mathrm{dm}$ crude protein, $2.45 \pm 0.01$ $\mathrm{g} / 100 \mathrm{~g} \mathrm{dm}$ ash, $32.48 \pm 0.40 \mathrm{~g} / 100 \mathrm{~g} \mathrm{dm}$ crude fiber, and $16.98 \pm 0.04 \mathrm{~g} / 100 \mathrm{~g} \mathrm{dm}$ total carbohydrates. Similar protein, ash, and fiber levels were reported in the seed cake by Chasquibol Silva and Yácono Llanos (2015).

\section{Optimization trials for oil screw-press extraction}

Table 1 reports the results of the oil extraction trials, while Figure 1 shows the response surface plots. The ANOVA (Table 2) highlighted significant effects of temperature and moisture on oil recovery and residual oil in the cake; the moisture presented the highest influence. While oil recovery showed a linear behavior, the residual oil showed a quadratic effect of temperature. Even if the lack-of-fit for both variables was significant, the adjusted- $R^{2}$ and predicted- $R^{2}$ were very high. During the extraction, the oil quality parameters were mainly influenced by the seed moisture and by its quadratic term for acid value and $p$-anisidine. All these models showed nonsignificant lack of fit and high $\mathrm{R}^{2}$.

The OR increased and the residual oil decreased significantly as the moisture content of the seeds and the pressing temperature decreased from 12 to $8 \%$ and from 100 to $60^{\circ} \mathrm{C}$, respectively (Figure 1). Similar trends were reported by Mridula et al. (2015) and Singh et al. (2002) during the screw-pressing oil extraction from, respectively, linseed (moisture $6-10 \% \mathrm{wb} ; 50-90^{\circ} \mathrm{C}$ ) and crambe seeds (moisture $3.6-9.2 \% \mathrm{dm} ; 120^{\circ} \mathrm{C}$ ). Similarly, Silvia et al. (2012) observed an increase of OR from nigella seeds with a pressing temperature decrease from 100 to $50^{\circ} \mathrm{C}$. According to Martínez et al. (2017) and
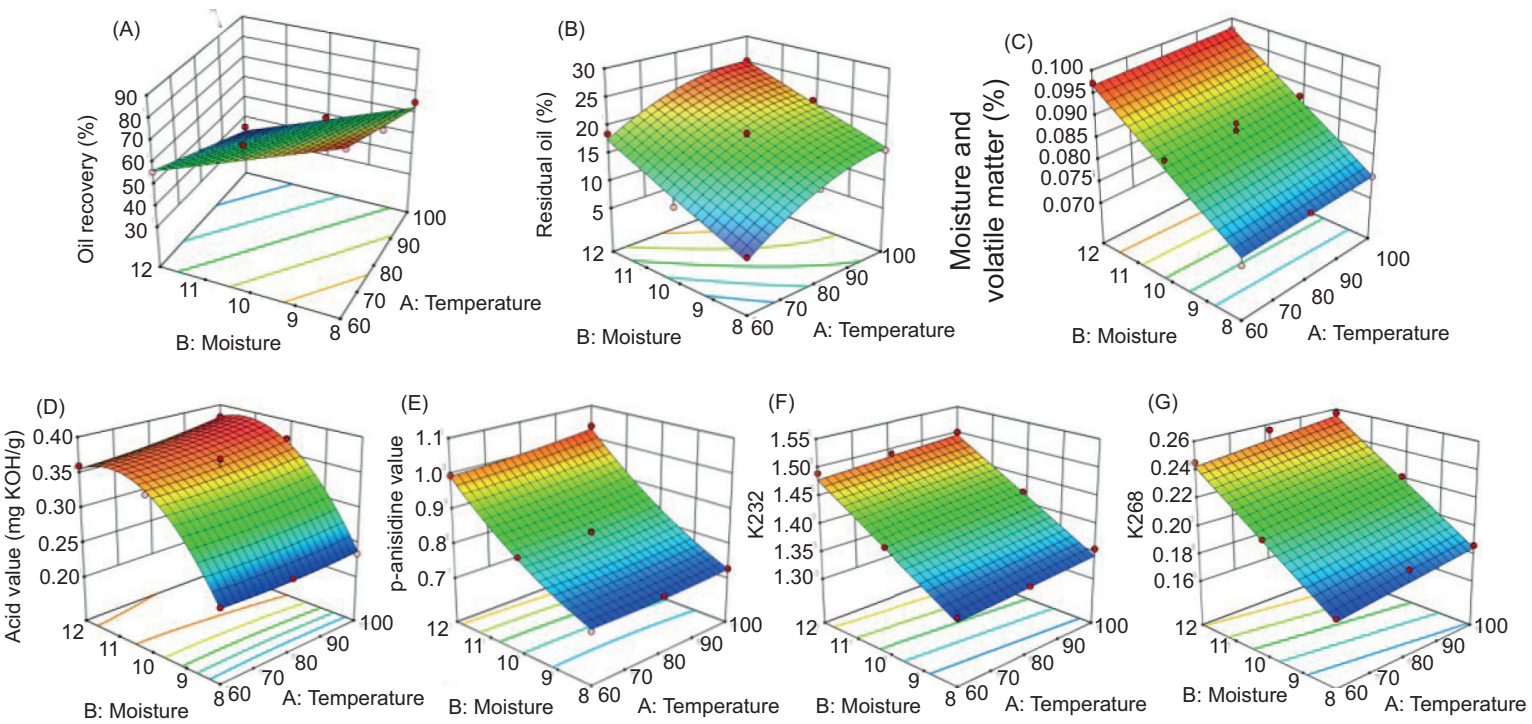

Figure 1. Response surface plots for oil recovery (A), residual oil in the cake (B), and physicochemical quality (moisture and volatile matter, $\mathrm{C}$; acid value, $\mathrm{D} ; \mathrm{p}$-anisidine value, $\mathrm{E} ; \mathrm{K}_{232}, \mathrm{~F} ; \mathrm{K}_{268}, \mathrm{G}$ ) of goldenberry seed oil as a function of moisture and temperature of press extraction. 
Table 2. Analysis of variance (mean square and significance) for oil recovery, residual oil in the cake, and physicochemical quality of goldenberry seed oil.

\begin{tabular}{|c|c|c|c|c|c|c|c|c|c|}
\hline Source & df & Oil recovery & Residual oil & $\begin{array}{c}\text { Moisture and } \\
\text { volatile matter }\end{array}$ & $\mathrm{K}_{232}$ & $\mathrm{~K}_{268}$ & df & Acid value & $p$-anisidine \\
\hline A-Temperature & 1 & $850.9^{\star \star \star}$ & $119.2^{\star \star * *}$ & $1.4 \times 10^{-6}$ & 0.0004 & 0.00023 & 1 & 0.00029 & $0.00059^{*}$ \\
\hline B-Moisture & 1 & $1358.1^{\star * *}$ & $158.9^{* * *}$ & $0.00076^{* * *}$ & $0.035^{\star * *}$ & $0.00737^{\star \star *}$ & 1 & $0.026^{\star * *}$ & $0.12^{\star \star \star}$ \\
\hline$A B$ & & & 1.37 & & & & 1 & 0.00015 & 0.00023 \\
\hline$A^{2}$ & & & $11.95^{*}$ & & & & 1 & 0.00004 & 0.00006 \\
\hline$B^{2}$ & & & 0.03 & & & & 1 & $0.009^{* * *}$ & $0.00205^{* *}$ \\
\hline Residual & 8 & 10.8 & 1.27 & $2.3 \times 10^{-6}$ & 0.00018 & 0.00005 & 5 & 0.00016 & 0.00009 \\
\hline Lack of Fit & 6 & $14.4^{*}$ & $2.10^{*}$ & $1.6 \times 10^{-6}$ & 0.00018 & 0.00007 & 3 & 0.00003 & 0.00015 \\
\hline Pure Error & 2 & 0.22 & 0.04 & $4.1 \times 10^{-6}$ & 0.00019 & 0.00001 & 2 & 0.00035 & $2.7 \times 10^{-6}$ \\
\hline $\mathrm{R}^{2}$ & & 0.96 & 0.98 & 0.98 & 0.96 & 0.95 & & 0.98 & 1.00 \\
\hline Adj- $R^{2}$ & & 0.95 & 0.96 & 0.97 & 0.95 & 0.93 & & 0.96 & 1.00 \\
\hline Pred- $R^{2}$ & & 0.93 & 0.81 & 0.96 & 0.93 & 0.92 & & 0.94 & 0.96 \\
\hline C.V. \% & & 5.50 & 5.58 & 1.75 & 0.96 & 3.46 & & 3.85 & 1.11 \\
\hline
\end{tabular}

df, degrees of freedom; Adj- $R^{2}, R^{2}$ adjusted by df; Pred- $R^{2}, R^{2}$ in prediction; ${ }^{*} P \leq 0.05 ;{ }^{* *} P \leq 0.01 ;{ }^{* * *} P \leq 0.001$.

Savoire et al. (2012), both high moisture content and high pressing temperature may result in poor OR due to excessive softening of the tissues, which makes seeds to stick and reduces friction.

The moisture and volatile matter were, respectively, in the range of 0.072 and $0.097 \%$, below the maximum limit (0.2\%) established by the Codex Alimentarius (1999a) for vegetable oils. The AVs were in the range of 0.234 and $0.382 \mathrm{mg} \mathrm{KOH} / \mathrm{g}$, below the maximum limit established by the Codex Alimentarius (1999a) for cold-pressed oils $(4 \mathrm{mg} \mathrm{KOH} / \mathrm{g})$ and refined oils $(0.6 \mathrm{mg} \mathrm{KOH} / \mathrm{g})$. We obtained quite low AV when compared to Mokhtar et al. (2018; $2.36 \mathrm{mg} \mathrm{KOH} / \mathrm{g})$, indicating that the applied treatments did not greatly increase the hydrolysis of fatty acids. In fact, unlike Mokhtar et al. (2018), in the present study, the seeds were separated from the pomace before grinding, probably reducing the contact between the oil and the endogenous hydrolytic enzymes.

The hydroperoxides were below the detection limit $(0.5$ $\mathrm{mEq}_{2} / \mathrm{kg}$; Frankel, 2012), suggesting that the treatments did not accelerate the oxidative process, likely due to the presence of natural antioxidants that may have delayed it. In fact, GSO is extremely rich in total tocopherols $(2400-5100 \mathrm{mg} / \mathrm{kg}$ ), with $\beta>\gamma-\delta>\alpha$ (Popova et al., 2020, 2021; Ramadan et al., 2008).

Specific extinctions in UV $\left(\mathrm{K}_{232}\right.$ and $\left.\mathrm{K}_{268}\right)$ are highly sensitive indices that measure the extent of oil oxidation. Conjugated dienes are detected at 232 (or 234) $\mathrm{nm}$ and derive from primary oxidation of linoleic acid, following the same trend of peroxides. Conjugated trienes are detected at 268 (or 270) $\mathrm{nm}$ and derive from primary oxidation of linolenic acid as well as from dehydration of hydroxy-linoleate or -linolenate (Frankel, 2012). The $\mathrm{K}_{232}$ and $\mathrm{K}_{268}$ ranged from 1.33 to 1.50 and 0.17 to 0.26 , respectively (Table 1 ). These values are in contrast with those of Ramadan et al. (2008), who reported $\mathrm{K}_{232}=0.57$ and $\mathrm{K}_{268}=1.02-1.12$ in goldenberry pomace oil processed by enzyme-aided aqueous and solvent extractions. However, the oil obtained by Ramadan et al. (2008) appeared to contain secondary oxidation products. In fact, as reported by Spatari et al. (2017) for several edible oils (soybean, olive, corn, linseed, sunflower, and peanut), UV absorbance spectra are always higher around $230 \mathrm{~nm}$ than around $270 \mathrm{~nm}$, and the primary oxidation mainly affects the absorbance in the former region.

The $p$-AVs were in the range of 0.72 and 1.04 , which is below the maximum limit (10.0) indicated by Matthäus (2010) for refined oils. The $p$-anisidine test detects high molecular weight carbonyl compounds (Frankel, 2012), thus a low value indicates that the oil is not in an advanced stage of oxidation, thereby supporting the fact that the applied treatments did not induce oil oxidation.

The values of all the physicochemical parameters decreased with the reduction of seeds' moisture from 12 to $8 \%$ except for $\mathrm{AV}$, whose values remained almost constant between 12 and $10 \%$ and decreased from 10 to $8 \%$ following a quadratic relation. In general, this parameter was not influenced by the pressing temperature (Table 2). Lipase, lipoxygenase, and phospholipase are activated at high moisture (>10\%; Gupta, 2002): this may explain why a predominant moisture effect on oil degradation indicators was observed. Besides, lipase exhibits hydrolytic activity only if sufficient water is available both as 
reactant and to form a water-oil interface (Brockman, 2013).

To find out the experimental conditions that maximize oil recovery and minimize other responses, a multi-response optimization by RSM was performed by using the desirability function. The solution we found had a desirability equal to 0.98 and corresponded to the treatment performed with $8 \%$ moisture at $60^{\circ} \mathrm{C}$. The maximum oil recovery $(86.43 \%)$ was far higher than the yield obtained by Ramadan and Moersel (2009; 42.1\%) with an enzymatic-aided aqueous extraction; this might be due to nonfatty matter retaining oil in the pomace. The OR observed in the present research was similar to those reported for screw-pressed flaxseed (82.9\%) and sesame (74.2\%) seeds (Martínez et al., 2017; Mridula et al., 2015). Therefore, screw-pressing of goldenberry seeds separated from pomace guarantee higher yields and better quality of oil.

\section{Characterization of the oil extracted at the optimized conditions}

\section{Physicochemical characteristics}

Table 3 shows the physicochemical characteristics of the GSO extracted at $60^{\circ} \mathrm{C}$ with $8 \%$ of final moisture. The iodine value, $140.5 \mathrm{~g} \mathrm{I}_{2} / 100 \mathrm{~g}$, is consistent with the theoretical value calculated as the average, weighted on the fatty acid composition, of the values provided by Gunstone (2004; 85.6, 173.2, and 260.3 for methyl oleate, linoleate, and linolenate, respectively). This places the goldenberry oil in a straddling position between semisiccative and siccative oils. The degree of unsaturation was also reflected by RI $\left(1.4769\right.$ at $\left.20^{\circ} \mathrm{C}\right)$. The IV and RI values were higher than those $\left(116.3 \mathrm{~g} \mathrm{I}_{2} / 100 \mathrm{~g}\right.$ and 1.4481, respectively) reported by Aslanov et al. (1995), likely due to a lower degree of unsaturation of the oil they analyzed. In fact, both IV and RI increase as the number of double bonds increases (Raziq et al., 2012). Mokhtar

Table 3. Physicochemical characteristics of goldenberry seed oil corresponding to the treatment with the highest oil recovery and the best quality $\left(8 \%\right.$ of final moisture, $\left.60^{\circ} \mathrm{C}\right)$.

\begin{tabular}{lc} 
Parameter & \\
\hline lodine value $\left(\mathrm{g} \mathrm{I}_{2} / 100 \mathrm{~g}\right)$ & $140.50 \pm 0.24$ \\
Refractive index $\left(20^{\circ} \mathrm{C}\right)$ & $1.4769 \pm 0.0001$ \\
Saponification value $(\mathrm{mg} \mathrm{KOH} / \mathrm{g})$ & $188.10 \pm 0.20$ \\
Unsaponifiable matter $(\mathrm{g} / 100 \mathrm{~g})$ & $1.67 \pm 0.02$ \\
Color coordinates: & \\
$L^{*}$ & $30.21 \pm 0.08$ \\
$a^{*}$ & $-2.13 \pm 0.01$ \\
$b^{*}$ & $10.03 \pm 0.11$ \\
\hline
\end{tabular}

et al. (2018) reported an IV of $109.5 \mathrm{~g} \mathrm{I}_{2} / 100 \mathrm{~g}$, despite their fatty acid composition being very similar to ours.

We determined a saponification value of $188.1 \mathrm{mg}$ $\mathrm{KOH} / \mathrm{g}$, similar to those observed by Mokhtar et al. (2018) in goldenberry pomace oil and by Anwar et al. (2002) in safflower oil, i.e., 186.2 and $189.0 \mathrm{mg} \mathrm{KOH} / \mathrm{g}$, respectively. The GSO's SV was lower than the SV of coconut, babassu, and palm kernel oils, where medium chain fatty acids (mainly lauric and myristic; Codex Alimentarius, 1999b) predominate. This indicates that long-chain fatty acids (C18) were more abundant in GSO, as SV decreases with fatty acid chain length.

The unsaponificable matter is the sum of minor but valuable components such as tocopherols, carotenoids, squalene, and phytosterols, which not only impart oxidative stability to the oils but also enhance their nutritional value (Raziq et al., 2012). The value we found, $1.67 \mathrm{~g} / 100 \mathrm{~g}$, is the average among edible oils, being very close to soybean, sunflower (both regular than high oleic), safflower, coconut, and cottonseed oil; conversely, corn oil has superior values, near to $3 \mathrm{~g} / 100 \mathrm{~g}$ (Codex Alimentarius, 1999b; Gunstone, 2004). Higher values were reported by Ramadan et al. (2008) and Popova et al. (2021): 2.13-2.25 and $3.02 \mathrm{~g} / 100 \mathrm{~g}$, respectively. According to Popova et al. (2021), the peel is the part richest in unsaponificable matter $(61.33 \mathrm{~g} / 100 \mathrm{~g}$ of peel oil), despite containing twofold less tocopherols and far less sterols than seeds. In our opinion, this is explained by the wax covering the fruit, which distorts the result. Instead, our experiments were conducted separating the seeds from the rest of the pomace.

The $L^{*}, a^{*}$, and $b^{*}$ coordinates were $30.21,-2.13$, and 10.03 , respectively. This indicated that the oil was slightly dark with the presence of yellow and, in lower degree, green compounds that likely correspond to pigments such as carotenoids and chlorophylls, respectively. The GSO coordinates in the CIELab system were lower than those reported for other oils, such as chia (Ixtaina et al., 2011), pistachio (Ling et al., 2016), and linseed (Varas Condori et al., 2020).

\section{Fatty acid composition}

Linoleic acid (C18:2 $\omega-6)$ was the most abundant fatty acid, followed by oleic (C18:1), palmitic (C16:0), stearic (C18:0), and vaccenic $(\mathrm{C} 18: 1 \omega 7)$ acids (Table 4$)$. The remaining unsaturated fatty acids (palmitoleic and $\alpha$-linolenic), as well as the long-chain saturated fatty acids (arachidic, behenic, and lignoceric) were found in low concentrations $(<0.5 \%)$. Similar results were reported by Mokhtar et al. (2018), Ramadan and Moersel (2009), Ramadan and Mörsel (2003), and Chasquibol Silva and Yácono Llanos 
Table 4. Fatty acid profile (\% of total FAME) of goldenberry seed oil corresponding to the treatment with the highest oil recovery and best quality $\left(8 \%\right.$ of final moisture, $\left.60^{\circ} \mathrm{C}\right)$.

\begin{tabular}{lr} 
Fatty acid & \\
\hline Palmitic acid (C16:0) & $6.43 \pm 0.01$ \\
Palmitoleic acid (C16:1 $\omega-7)$ & $0.40 \pm 0.02$ \\
Stearic acid (C18:0) & $3.23 \pm 0.01$ \\
Oleic acid (C18:1 $\omega-9)$ & $10.97 \pm 0.06$ \\
Vaccenic acid (C18:1 $\omega-7)$ & $1.67 \pm 0.01$ \\
Linoleic acid (C18:2 $\omega-6)$ & $75.99 \pm 0.02$ \\
$\alpha$-linolenic acid (C18:3 $\omega-3)$ & $0.23 \pm 0.00$ \\
Arachidic acid (C20:0) & $0.40 \pm 0.01$ \\
Behenic acid (C22:0) & $0.16 \pm 0.01$ \\
Lignoceric acid (C24:0) & $0.16 \pm 0.00$ \\
\hline Saturated fatty acids & $10.37 \pm 0.01$ \\
Unsaturated fatty acids & $89.25 \pm 0.11$ \\
$\quad$ Monounsaturated & $13.03 \pm 0.04$ \\
\multicolumn{1}{l}{ Polyunsaturated } & $76.22 \pm 0.02$ \\
\hline
\end{tabular}

(2015), although they found lower contents of $\alpha$-linolenic and vaccenic acids. Aslanov et al. (1995) reported higher values of palmitic, oleic, and $\alpha$-linolenic acids, lower values of linoleic acid, but similar percentage of stearic acid. Our results were also quite similar to Embaby et al. (2022), who found slightly higher amounts of stearic, behenic, lignoceric, and $\alpha$-linolenic acids offset by lower contents of linoleate and palmitate. Differences in oil composition may be explained by different origin, environment, growing conditions, and oil extraction process (Varas Condori et al., 2020). In fact, for two genotypes of goldenberry, Popova et al. (2020) reported extremely discordant values for fatty acids: palmitic $20.6-20.9 \%$, stearic $13.0-17.5 \%$, oleic 5.4-29.4\%, linoleic 5.3-11.3, and $\alpha$-linolenic 5.4$9.2 \%$. Comparing other oil species, GSO appears very similar to regular safflower oil (Anwar et al., 2002; Codex Alimentarius, 1999b; Gunstone, 2004).

Linoleic acid derivatives serve as structural components of the plasma membrane and as precursors of some metabolic regulatory compounds. In addition, studies suggest that linoleic acid consumption is inversely correlated with the risk of cardiovascular diseases (Marangoni et al., 2020); thus, introducing GSO in diet could help maintain an adequate health.

\section{Shelf-life prediction}

The OSI at $100^{\circ} \mathrm{C}$ was $14.87 \mathrm{~h}$ (Table 5), higher than the values reported for other crude oils such as camelina (5.21 h; Ratusz et al., 2016), linseed (4.07 h; Varas Condori et al., 2020), chia (3.03 h; Villanueva et al., 2017), and sacha inchi (1.59 h; Rodríguez et al., 2015) but lower than crude pumpkin oil (18.2 h; Vujasinovic et al., 2010).
These differences could be due to the different fatty acids' profile, since OSI decreases as the degree of unsaturation increases (Shadyro et al., 2017).

The relationship between OSI and temperature was linearized through logarithm transformation. The line of regression showed a high coefficient of determination $\left(\mathrm{R}^{2}=0.9994\right)$, thus $99.94 \%$ of OSI variation was explained by the model. The predicted shelf life at $25^{\circ} \mathrm{C}$ was 120 days (approximately 4 months), very close to the 118.9-123.2 days of two chia:sesame oil blends studied by Rodríguez et al. (2020), higher than the 91 days reported for crude linseed oil by Varas Condori et al. (2020), but lower than the 386 and 211 days of, respectively, pistachio (Dini et al., 2016) and avocado (Aktar and Adal, 2019) crude oils. In comparison with commercial oils, whose shelf life generally is between 12 and 15 months under normal storage conditions, GSO predicted shelf life was low (Kochhar and Henry, 2009). Taking into account that the GSO started with very low levels of deterioration (Table 1), the short time obtained can be attributed to the high concentration of linoleic acid, which oxidizes 10- 40 times faster than the oleic acid (Symoniuk et al., 2016).

\section{Oxidation kinetics}

The $k$ constant increased as a function of the temperature (Table 5) since the oxidation rate was accelerated by the temperature increase. The magnitude of the effect of temperature on $k$ was demonstrated by $\mathrm{Q}_{10}$, which had a value of 2.02. Similar values were reported in refined soybean oils (1.99-2.08; Farhoosh, 2007) and crude linseed oils (1.99-2.05; Symoniuk et al., 2017), while lower values were reported in crude canola oils (1.84-1.86; Symoniuk et al., 2016). A high $\mathrm{Q}_{10}$ implies that small changes in temperature induce a greater increase in the reaction rate, so that high $\mathrm{Q}_{10}$ values indicate lower oxidative stability (Farhoosh et al., 2008; Symoniuk et al., 2016).

The GSO oxidation kinetics obeyed the Arrhenius equation (Table 5) in the temperature range from 100 to $120^{\circ} \mathrm{C}\left(\mathrm{R}^{2}=0.9988\right)$. The activation energy gives an indication of the minimum amount of energy needed to initiate the oxidation reaction. The $E a$ of GSO was $85.56 \mathrm{~kJ} / \mathrm{mol}$, slightly higher than the levels reported for camelina (70.39-79.08 kJ/mol; Ratusz et al., 2016), linseed (74.03-77.76 kJ/mol; Symoniuk et al., 2016), canola (75.73-77.64 kJ/mol; Symoniuk et al., 2017), and chia (82.0 kJ/mol; Rodríguez et al., 2020) crude oils but below the $E a$ of sesame $(96.2 \mathrm{~kJ} / \mathrm{mol}$; Rodríguez et al., 2020), hazelnut (94.75 kJ/mol; Gülmez and Şahin, 2019), and avocado (99.6 kJ/mol; Aktar and Adal, 2019) crude oils. These differences may be due to several factors, such as the degree of unsaturation and the presence of different 


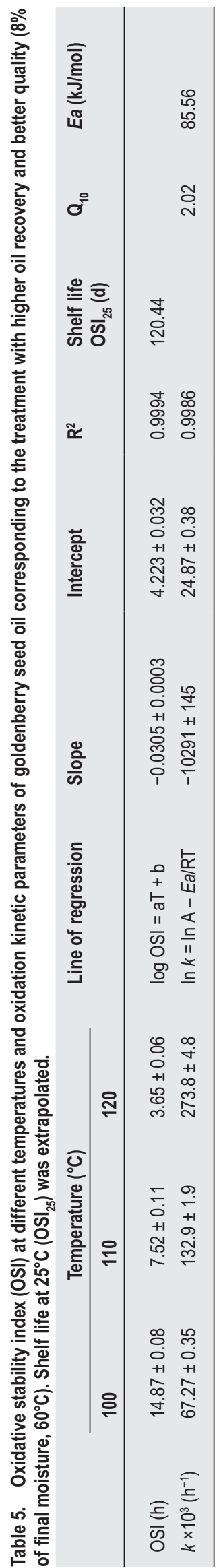

endogenous antioxidants or prooxidants (Symoniuk et al., 2017).

\section{Conclusions}

The pressing temperature and the moisture content of the seeds exerted a significant, but negative, effect on the OR. On the other hand, the seeds' moisture content affected the physicochemical quality of the oil to a greater extent than the pressing temperature. All the extraction conditions allowed to obtain oils with good physicochemical quality, but the best quality and the highest OR were achieved at $60^{\circ} \mathrm{C}$ with $8 \%$ of moisture content. Under these extraction conditions, the oil exhibited a yellow tone with low luminosity, presented high iodine value and refractive index, and low saponification value. In addition, GSO consisted mainly of unsaturated fatty acids, with a high percentage of linoleic acid $(\omega-6)$, which makes it an important source of this essential fatty acid. The oil presented a low oxidative stability that resulted in a shelf life of 120 days at $25^{\circ} \mathrm{C}$; the $E a$ was $85.56 \mathrm{~kJ} / \mathrm{mol}$. Finally, the results highlighted that screw-pressing of goldenberry seeds provides quality oil without employing polluting and hazardous solvents.

\section{Authors' Contribution}

Pedro P. Ugarte-Espinoza designed the study, collected and analyzed the data, and drafted the manuscript; Victor Delgado-Soriano supervised the work, collected and analyzed the data, and revised the manuscript; Lorenzo Estivi and Alyssa Hidalgo statistically elaborated the data, and drafted and revised the manuscript; Gloria Pascual-Chagman planned and designed the study, supervised the work, provided resources, and revised the manuscript.

\section{Conflict of Interest}

The authors declare that they have no conflicts of interest concerning this article. There was no financial support, except those mentioned in the acknowledgments.

\section{References}

Aktar, T. and Adal, E., 2019. Determining the Arrhenius kinetics of avocado oil: oxidative stability under Rancimat test conditions. Foods 8: 236. https://doi.org/10.3390/foods8070236

Anwar, F., Bhanger, M.I., Nasir, M.K.A. and Ismail, S., 2002. Analytical characterization of Salicornia bigelovii seed oil cultivated in Pakistan. Journal of Agricultural and Food Chemistry 50: 4210-4214. https://doi.org/10.1021/jf0114132 
AOAC International, 2016. Official methods of analysis of AOAC International. 20th ed. AOAC International, Rockville, MD.

AOCS-American Oil Chemists' Society, 1998. Official methods and recommended practices of the AOCS. 5th ed. AOCS Press, IL.

Aslanov, S.M., Mamedova, M.E. and Bairamova, S.A., 1995. Oil from the fruit and seeds of Physalis peruviana. Chemistry of Natural Compounds 31: 410-411. https://doi.org/10.1007/ BF01165216

Brockman, H.L., 2013. Lipases. In: Lennarz, W.J. and Lane, M.D. (eds.) Encyclopedia of biological chemistry.Vol. II. Academic Press, London, pp. 729-732.

Chasquibol Silva, N. and Yácono Llanos, J.C., 2015. Composición fitoquímica del aceite de las semillas del fruto del "Aguaymanto", Physalis peruviana L. Revista de la Sociedad Química del Perú 81: 311-318. https://doi.org/10.37761/RSQP.V81I4.36

Codex Alimentarius, 1999a. Codex standard for edible fats and oils not covered by individual standards (CODEX STAN 19-1981, Rev. 2 1999). Available at: http://www.fao.org/3/y2774e/y2774e03.htm.

Codex Alimentarius, 1999b. Codex standard for named vegetable oils (CODEX-STAN 210 - 1999). Available at: http://www.fao. org/3/y2774e/y2774e04.htm.

Deli, S., Farah Masturah, M., Tajul Aris, Y. and Wan Nadiah, W.A., 2011. The effects of parameters of the screw press oil expeller on oil yield from Nigella sativa L seeds. International Food Research Journal 18: 1367-1373.

Dini, A., Farrokhi, H., Sedaghat, N., Bagheri, M. and Mohammadkhani, N., 2016. Evaluation of oxidative stability and shelf-life prediction of pistachio oil using Rancimat. Journal of Rafsanjan University of Medical Sciences 15: 399-412.

Embaby, H.E., Miyakawa, T., Hachimura, S., Muramatsu, T., Nara, M. and Tanokura, M., 2022. Crystallization and melting properties studied by DSC and FTIR spectroscopy of goldenberry (Physalis peruviana) oil. Food Chemistry 366: 130645. https://doi.org/10.1016/j.foodchem.2021.130645

Etzbach, L., Pfeiffer, A., Weber, F. and Schieber, A., 2018. Characterization of carotenoid profiles in goldenberry (Physalis peruviana L.) fruits at various ripening stages and in different plant tissues by HPLC-DAD-APCI-MS ${ }^{\mathrm{n}}$. Food Chemistry 245: 508-517. https://doi.org/10.1016/j.foodchem.2017.10.120

Farhoosh, R., 2007. Shelf-life prediction of edible fats and oils using Rancimat. Lipid Technology 19: 232-234. https://doi. org/10.1002/lite.200700073

Farhoosh, R., Niazmand, R., Rezaei, M. and Sarabi, M., 2008. Kinetic parameter determination of vegetable oil oxidation under Rancimat test conditions. European Journal of Lipid Science and Technology 110: 587-592. https://doi.org/10.1002/ ejlt.200800004

Frankel, E.N., 2012. Lipid oxidation. 2nd ed. Woodhead Publishing Limited, Philadelphia, PA.

Gunstone, F.D., 2004. The chemistry of oils and fats: sources, composition, properties and uses. Blackwell Publishing, CRC Press, Oxford.

Gülmez, Ö. and Şahin, S., 2019. Evaluation of oxidative stability in hazelnut oil treated with several antioxidants: kinetics and thermodynamics studies. LWT - Food Science and Technology 111: 478-483. https://doi.org/10.1016/j.lwt.2019.05.077
Gupta, M.K., 2002. Sunflower oil. In: F.D. Gunstone (ed.) Vegetable oils in food technology: composition, properties and uses. Blackwell Publishing, Oxford, pp. 128-156.

Heidarpour, M. and Farhoosh, R., 2018. A preliminary Rancimat based kinetic approach of detecting olive oil adulteration. LWT - Food Science and Technology 90: 77-82. https://doi. org/10.1016/j.lwt.2017.12.015

ISO (International Organization for Standardization), 2011. ISO 3656:2011. Animal and vegetable fats and oils - determination of ultraviolet absorbance expressed as specific UV extinction. International Organization for Standardization. Geneva, Switzerland.

IUPAC (International Union of Pure and Applied Chemistry), 1987. IUPAC standard methods 2.302. Standard methods for the analysis of oils, fats and derivates. Blackwell Scientific, Oxford.

Ixtaina, V.Y., Martínez, M.L., Spotorno, V., Mateo, C.M., Maestri, D.M., Diehl, B.W.K., Nolasco, S.M. and Tomás, M.C., 2011. Characterization of chia seed oils obtained by pressing and solvent extraction. Journal of Food Composition and Analysis 24: 166-174. https://doi.org/10.1016/j.jfca.2010.08.006

Kochhar, P. and Henry, C.J.K., 2009. Oxidative stability and shelflife evaluation of selected culinary oils. International Journal of Food Sciences and Nutrition 60(S7): 289-296. https://doi. org/10.1080/09637480903103774

Ling, B., Yang, X., Li, R. and Wang, S., 2016. Physicochemical properties, volatile compounds, and oxidative stability of cold pressed kernel oils from raw and roasted pistachio (Pistacia vera L. Var Kerman). European Journal of Lipid Science and Technology 118: 1368-1379. https://doi.org/10.1002/ejlt.201500336

Marangoni, F., Agostoni, C., Borghi, C., Catapano, A.L., Cena, H., Ghiselli, A., La Vecchia, C., Lercker, G., Manzato, E., Pirillo, A., Riccardi, G., Risé, P., Visioli, F. and Poli, A., 2020. Dietary linoleic acid and human health: focus on cardiovascular and cardiometabolic effects. Atherosclerosis 292: 90-98. https://doi. org/10.1016/j.atherosclerosis.2019.11.018

Martínez, M.L., Bordón, M.G., Lallanas, R.L., Ribotta, P.D. and Maestri, D.M., 2017. Optimization of sesame oil extraction by screwpressing at low temperature. Food and Bioprocess Technology 10: 1113-1121. https://doi.org/10.1007/s11947-017-1885-4.

Matthäus, B., 2010. Oxidation of edible oils. In: E.A Decker, R.J. Elias and D.J. McClements (eds.) Oxidation in foods and beverages and antioxidant applications. Vol. II. Woodhead Publishing Limited, Cambridge, p. 528.

Mokhtar, S.M., Swailam, H.M. and Embaby, H.E.-S., 2018. Physicochemical properties, nutritional value and technofunctional properties of goldenberry (Physalis peruviana) waste powder concise title: composition of goldenberry juice waste. Food Chemistry 248: 1-7. https://doi.org/10.1016/j. foodchem.2017.11.117

Mridula, D., Barnwal, P. and Singh, K.K., 2015. Screw pressing performance of whole and dehulled flaxseed and some physicochemical characteristics of flaxseed oil. Journal of Food Science and Technology 52: 1498-1506. https://doi.org/10.1007/ s13197-013-1132-6

Mridula, D., Saha, D., Gupta, R.K. and Bhadwal, S., 2019. Oil expelling of dehulled sunflower: optimization of screw pressing 
parameters. Journal of Food Processing and Preservation 43: e13852. https://doi.org/10.1111/jfpp.13852

Mwaurah, P.W., Kumar, S., Kumar, N., Attkan, A.K., Panghal, A., Singh, V.K. and Garg, M.K., 2020. Novel oil extraction technologies: process conditions, quality parameters, and optimization. Comprehensive Reviews in Food Science and Food Safety 19: 3-20. https://doi.org/10.1111/1541-4337.12507

Nocetti, D., Núñez, H., Puente, L., Espinosa, A. and Romero, F., 2020. Composition and biological effects of goldenberry byproducts: an overview. Journal of the Science of Food and Agriculture 100: 4335-4346. https://doi.org/10.1002/jsfa.10386

Popova, V., Petkova, Z., Ivanova, T., Stoyanova, M., Mazova, N. and Stoyanova, A., 2021. Lipid composition of different parts of cape gooseberry (Physalis peruviana L.) fruit and valorization of seed and peel waste. Grasas y Aceites 72(2): e402. https://doi. org/10.3989/gya.1256192

Popova, V., Petkova, Z, Ivanova, T., Stoyanova, M., Panayotov, N., Mazova, N. and Stoyanova, A., 2020. Determination of the chemical composition of seeds, peels, and seedcakes from two genotypes of cape gooseberry (Physalis peruviana L.). Turkish Journal of Agriculture and Forestry 44: 642-650. https://doi. org/10.3906/tar-2003-66

Ramadan, M.F., 2020. Bioactive phytochemicals of cape gooseberry (Physalis peruviana L.). In: H.N. Murthy and V.A. Bapat (eds.) Bioactive compounds in underutilized fruits and nuts. Springer Nature, p. 665.

Ramadan, M.F. and Moersel, J.T., 2009. Oil extractability from enzymatically treated goldenberry (Physalis peruviana L.) pomace: range of operational variables. International Journal of Food Science \& Technology 44: 435-444. https://doi. org/10.1111/j.1365-2621.2006.01511.x

Ramadan, M.F. and Moersel, J.T., 2003. Oil goldenberry (Physalis peruviana L.). Journal of Agricultural and Food Chemistry 51: 969-974. https://doi.org/10.1021/jf020778z

Ramadan, M.F., Sitohy, M.Z. and Moersel, J.T., 2008. Solvent and enzyme-aided aqueous extraction of goldenberry (Physalis peruviana L.) pomace oil: impact of processing on composition and quality of oil and meal. European Food Research and Technology 226: 1445-1458. https://doi.org/10.1007/ s00217-007-0676-y

Ratusz, K., Popis, E., Ciemniewska-Żytkiewicz, H. and Wroniak, M., 2016. Oxidative stability of camelina (Camelina sativa L.) oil using pressure differential scanning calorimetry and Rancimat method. Journal of Thermal Analysis and Calorimetry 126: 343351. https://doi.org/10.1007/s10973-016-5642-0

Raziq, S., Anwar, F., Mahmood, Z., Shahidi, S.A. and Nadeem, R., 2012. Characterization of seed oils from different varietes of watermelon [Citrullus lanatus (Thunb.)] from Pakistan. Grasas y Aceites 63: 365-372. https://doi.org/10.3989/gya.022212

Rodríguez, G., Squeo, G., Estivi, L., Quezada Berru, S., Buleje, D., Caponio, F., Brandolini, A. and Hidalgo, A., 2021. Changes in stability, tocopherols, fatty acids and antioxidant capacity of sacha inchi (Plukenetia volubilis) oil during French fries deep-frying. Food Chemistry 340: 127942. https://doi. org/10.1016/j.foodchem.2020.127942
Rodríguez, G., Villanueva, E., Cortez, D., Sanchez, E., Aguirre, E. and Hidalgo, A., 2020. Oxidative stability of chia (Salvia hispanica L.) and sesame (Sesamum indicum L.) oil blends. Journal of the American Oil Chemists' Society 97: 729-735. https://doi.org/10.1002/aocs.12357

Rodríguez, G., Villanueva, E., Glorio, P. and Baquerizo, M., 2015. Estabilidad oxidativa y estimación de la vida útil del aceite de sacha inchi (Plukenetia volubilis L.). Scientia Agropecuaria 6: 155-163. https://doi.org/10.17268/sci.agropecu.2015.03.02

Savoire, R., Lanoisellé, J.L. and Vorobiev, E., 2012. Mechanical continuous oil expression from oilseeds: a review. Food and Bioprocess Technology 6: 1-16. https://doi.org/10.1007/s11947-012-0947-x

Shadyro, O.I., Sosnovskaya, A.A. and Edimecheva, I.P., 2017. Flaxseed oil stabilization using natural and synthetic antioxidants. European Journal of Lipid Science and Technology 119: 1700029. https://doi.org/10.1002/ejlt.201700079

Silvia, D., Farah Masturah, M., Tajul Aris, Y., Wan Nadiah, W.A. and Bhat, R., 2012. The effects of different extraction temperatures of the screw press on proximate compositions, amino acid contents and mineral contents of Nigella sativa meal. American Journal of Food Technology 7: 180-191. https://doi.org/10.3923/ ajft.2012.180.191

Singh, K.K., Wiesenborn, D.P., Tostenson, K. and Kangas, N., 2002. Influence of moisture content and cooking on screw pressing of crambe seed. Journal of the American Oil Chemists' Society 79: 165-170. https://doi.org/10.1007/s1174.6-002-0452-3

Singh, J. and Bargale, P.C., 2000. Development of a small capacity double stage compression screw press for oil expression. Journal of Food Engineering 43: 75-82. https://doi.org/10.1016/ S0260-8774.(99)00134-X

Spatari, C., De Luca, M., Ioele, G. and Ragno, G., 2017. A critical evaluation of the analytical techniques in the photodegradation monitoring of edible oils. LWT - Food Science and Technology 76: 147-155. https://doi.org/10.1016/j.lwt.2016.10.055

Symoniuk, E., Ratusz, K. and Krygier, K., 2016. Comparison of the oxidative stability of linseed (Linum usitatissimum L.) oil by pressure differential scanning calorimetry and Rancimat measurements. Journal of Food Science and Technology 53: 39863995. https://doi.org/10.1007/s13197-016-2398-2

Symoniuk, E., Ratusz, K. and Krygier, K., 2017. Comparison of the oxidative stability of cold-pressed rapeseed oil using pressure differential scanning calorimetry and Rancimat methods. European Journal of Lipid Science and Technology 119: 1600182. https://doi.org/10.1002/ejlt.201600182

Varas Condori, M., Pascual Chagman, G., Barriga Sanchez, M.E., Villegas Vilchez, L.F., Ursetta, S., Guevara, A. and Hidalgo, A., 2020. Effect of tomato (Solanum lycopersicum L.) lycopene-rich extract on the kinetics of rancidity and shelf-life of linseed (Linum usitatissimum L.) oil. Food Chemistry 302: 125327. https://doi.org/10.1016/j.foodchem.2019.125327

Vásquez-Parra, J.E., Ochoa-Martínez, C.I. and Bustos-Parra, M., 2013. Effect of chemical and physical pretreatments on the convective drying of cape gooseberry fruits (Physalis peruviana). Journal of Food Engineering 119: 648-654. https://doi. org/10.1016/j.jfoodeng.2013.06.037 
Villanueva, E., Rodríguez, G., Aguirre, E. and Castro, V., 2017. Influencia de antioxidantes en la estabilidad oxidativa del aceite de chía (Salvia hispanica L.) por Rancimat. Scientia Agropecuaria 8: 19-27. https://doi.org/10.17268/sci.agropecu. 2017.01.02
Vujasinovic, V., Djilas, S., Dimic, E., Romanic, R. and Takaci, A., 2010. Shelf life of cold-pressed pumpkin (Cucurbita pepo L.) seed oil obtained with a screw press. Journal of the American Oil Chemists' Society 87: 1497-1505. https://doi.org/10.1007/ s11746-010-1630-x 